\title{
Perbaikan Rancangan Tata Letak Lantai Produksi di CV. XYZ
}

\author{
Nunung Nurhasanah ${ }^{1}$, Bima Prasetya Simawang ${ }^{1}$ \\ ${ }^{1}$ Teknik Industri, Fakultas Sains dan Teknologi, Universitas Al Azhar Indonesia, Komplek Masjid Agung, \\ Jalan Sisingamangaraja, Kebayoran Baru, Jakarta Selatan 12110
}

Tel. 7244456, fax. 7244767, email: nunungnurhasanah@uai.ac.id

\begin{abstract}
Abstrak - Perancangan Tata letak fasilitas adalah perencanaan dan integrasi aliran komponenkomponen suatu produk untuk mendapatkan interelasi yang paling efektif dan efisien antar operator, peralatan, dan proses transformasi material dari bagian penerimaan sampai ke bagian pengiriman produk jadi. Penelitian ini bertujuan untuk menganalisis dan merancang tata letak fasilitas lantai produksi berdasarkan jarak perpindahan material yang minimum di CV. XYZ. Penelitian diawali dengan menentukan produk yang akan dijadikan sebagai objek penelitian. Langkah-langkah berikutnya adalah menentukan jumlah mesin teoritis dengan Routing Sheet; tentukan jumlah mesin sebenarnya dengan Multi Product Process Chart; menentukan luas lantai produksi, luas gudang bahan baku, dan luas gudang barang jadi; menghitung Material Handling Planning Sheet (MHPS) dengan menggunakan pendekatan Fuzzy Layout Trapezoidal; membuat From To Chart (FTC); dan membuat tabel skala prioritas. Perhitungan hasil rancangan yang optimal dengan menggunakan 3 metode, yaitu Relationship Diagramming Method (RDM), Hollier 1 Method, dan Hollier 2 Method. Dari ketiga metode tersebut dipilih hasil dari perhitungan total yang memilliki jarak rectilinear yang terkecil. Dari tiga metode yang digunakan didapatkan hasil total jarak terkecil 82.65 meter berdasarkan RDM.
\end{abstract}

Abstract - Layout of the facility as the planning and integration of the flow components of a product to get interelation the most effective and efficient among operators, equipment, and process of the transformation of material from the reception through to the delivery of finished products. This research aims to analyze and design the layout of the floor production facilities based on the minimum distance of displacement of material in CV.XYZ. Initialing we determined the product as a research object, then specify the number of machines with the theoretical Routing Sheet, after it was determined the number of actual machine with Multi Product Process Chart, then determine the area of the production floor, spacious warehouses, raw materials and finished goods warehouse area, then calculate the Material Handling Planning Sheet (MHPS) using Fuzzy Trapezoidal Layout approach, then make a From To Chart (FTC), then make the table a priority scale. To calculate the optimal design we need three methods, namely Relationship Diagramming Method, Hollier 1 Method, and the Hollier 2 Method and then results from the third such methods as compared to the results of the calculation of total distance and initial layout selected a rectilinear distance with the smallest result. The results of data processing in this research is total distance most efficient is the total distance smallest among early layout and also layouts proposal obtained by using third method is as much as 826,5 meters. Total distance displacement material between machine is 98.5 meters, using the relationship layout diagramming method.

Keywords - Layout, Floor Area, Distance, Material, Machine

\section{PENDAHULUAN}

$\mathrm{T}$ ata letak fasilitas adalah suatu landasan utama dalam dunia industri. Tata letak fasilitas adalah perencanaan dan integrasi aliran komponenkomponen suatu produk untuk mendapatkan interelasi yang paling efektif dan efisien antar operator, peralatan, dan proses transformasi 
material dari bagian penerimaan sampai ke bagian pengiriman produk jadi [1].

Tujuan perancangan tata letak ini berhubungan erat dengan strategi manufaktur. Strategi ini umumnya melibatkan beberapa kriteria seperti ongkos, kualitas produk, utilitas sumber daya, waktu pengiriman, persediaan, dan keamanan kerja. Dalam perencanaan tata letak lantai produksi, maka harus pula dipikirkan mengenai sistem pemindahan barang (material handling). Pada proses produksi yang menggunakan mesin-mesin yang bekerja khusus, maka pemindahan barang antar mesin harus dilakukan dengan efektif dan efisien.

CV.XYZ adalah salah satu perusahaan yang bergerak di bidang pengolahan kayu yaitu memproduksi lemari pakaian. Keadaan lantai produksi di CV.XYZ saat ini, masih belum tersusun dengan tepat. Hal ini dapat dilihat dari bentuk pola aliran bahan yang ada, yang masih tidak teratur sehingga menyebabkan timbulnya back-tracking dari perpindahan bahan di dalam proses produksi. Hal ini mengakibatkan jarak perpindahan menjadi lebih jauh. Penempatan bahan-bahan yang akan diproses antara mesin yang satu dengan yang lain masih belum tersusun dengan teratur yang mengganggu kegiatan pemindahan bahan sehingga dapat mengakibatkan waktu pemindahan semakin lama. Di samping itu penempatan mesin-mesin dan peralatan yang digunakan belum sesuai dengan keterkaitan kebutuhan proses produksi.

Berdasarkan latar belakang di atas maka perumusan permasalahannya adalah sebagai berikut:

1. Menentukan tata letak fasilitas usulan yang memiliki jarak perpindahan material yang lebih kecil dari tata letak fasilitas lantai produksi yang digunakan perusahaan saat ini.

2. Menghitung pengurangan yang terjadi pada total jarak perpindahan material antar mesin.

Dari perumusan permasalahan di atas, tujuan yang ingin didapatkan adalah:

1. Menganalisis tata letak fasilitas lantai produksi CV.XYZ saat ini.

2. Merancang tata letak fasilitas lantai produksi berdasarkan jarak perpindahan material yang minimum.

\section{TINJAUAN PUSTAKA}

\section{Perancangan Tata Letak Pabrik}

Tata letak pabrik (plant layout) atau tata letak fasilitas (facilities layout) adalah tata cara pengaturan fasilitas-fasilitas pabrik guna menunjang kelancaran proses produksi, di mana dalam pengaturan tersebut akan dilakukan pemanfaatan luas area (space) untuk penempatan mesin atau fasilitas penunjang produksi lainnya, kelancaran gerakan pemindahan material, penyimpanan material (storage) baik yang bersifat temporer maupun permanen, personil pekerja dan sebagainya. Tata letak pabrik berhubungan erat dengan segala proses perencanaan dan pengaturan letak dari mesin, peralatan, aliran bahan, dan manusia yang bekerja di masing-masing stasiun kerja yang ada [2].

\section{Peta Proses Operasi}

Peta proses operasi menggambarkan langkahlangkah operasi dan pemeriksaan yang dialami bahan atau bahan-bahan dalam urutan-urutannya sejak awal sampai menjadi barang jadi utuh maupun sebagai bagian setengah jadi dan memuat informasi-informasi yang diperlukan untuk analisa lebih lanjut, seperti: waktu yang dihabiskan, material yang digunakan, dan tempat atau alat atau mesin yang dipakai [3].

\section{Routing Sheet}

Routing Sheet berguna untuk menghitung jumlah mesin yang dibutuhkan dan untuk menghitung jumlah part yang harus dipersiapkan dalam usaha memperoleh sejumlah produk jadi yang diinginkan. Routing Sheet adalah tabulasi langkah-langkah yang harus dilakukan dalam memproduksi komponen-komponen tertentu [4].

\section{Multi Product Process Chart (MPPC)}

Multi-Product Process Chart (MPPC) adalah sebuah peta yang digunakan untuk menggambarkan aliran atau urutan operasi kerja yang menghasilkan produk dengan banyak jenis, atau produk dengan banyak part. Peta ini terutama berguna untuk menunjukkan keterkaitan produksi antara komponen produk-produk atau antar produk, bahan, part, pekerjaan, atau kegiatan [2].

\section{Material Handling}

Material handling merupakan penanganan material dalam jumlah yang tepat dari material yang sesuai dalam kondisi yang baik pada tempat yang cocok, pada waktu yang tepat dalam posisi yang benar, dalam urutan yang sesuai dan biaya yang murah 
dengan menggunakan metode yang benar. Perencanaan material handling penting sekali dipelajari karena kenyataan yang ada menunjukkan bahwa biaya material handling menyerap sebagian biaya produksi [5].

\section{Sistem Fuzzy}

Logika fuzzy adalah suatu cara yang tepat untuk memetakan suatu ruang input ke dalam suatu ruang output. Dengan sistem fuzzy dapat ditentukan nilai tunggal dari beberapa nilai yang berbeda karena pendapat yang berlainan tentang suatu besaran [6].

\section{Fuzzifikasi}

Bilangan fuzzy dapat diproses secara matematik fuzzy sesuai dengan metode representasi.

\section{Defuzzifikasi \\ Defuzzifikasi merupakan suatu proses mengembalikan output fuzzy ke output yang bernilai tunggal (crisp).}

\section{Fuzzy Facility Layout Problem}

Teori fuzzy set adalah pendefinisian yang paling sempurna untuk memodelkan ketidakpastian [7]. Kemampuan fuzzy set dalam mengatasi ketidakpastian sangat penting untuk semua situasi pada saat informasi yang tersedia tidak tepat dan ketidakpastian yang berhubungan dengan data tidak dapat dihindarkan. Ketidakpastian aliran material diantara fasilitas biasanya digambarkan dengan convex fuzzy number, yang biasa disebut juga dengan fuzzy interflow. Fuzzy number yang biasa digunakan untuk menggambarkan fuzzy interflow adalah trapezoidal fuzzy number (TrFN).

\section{From To Chart}

From-To Chart (FTC) merupakan suatu teknik konvensional yang umum digunakan untuk perencanaan tata letak pabrik dan pemindahan bahan dalam suatu proses produksi, terutama sangat berguna untuk kondisi dimana terdapat banyak produk atau item yang mengalir melalui suatu area [3].

\section{Tabel Skala Prioritas}

Tabel skala prioritas (TSP) adalah suatu tabel yang menggambarkan urutan prioritas antara departemen/mesin dalam suatu lintas/layout produksi. Referensi TSP didapat dari perhitungan Outflow-Inflow, di mana prioritas diurutkan berdasarkan harga koefisien ongkosnya [1].

\section{Relationship Diagramming Method}

Activity Relationship Diagram atau Diagram Hubungan Kerja kegiatan adalah aktifitas atau kegiatan antara masing-masing bagian yang menggambarkan penting tidaknya kedekatan ruangan. Dalam suatu organisasi pabrik harus ada hubungan yang terikat antara suatu kegiatan dengan kegiatan lainnya yang dianggap penting dan selalu berdekatan demi kelancaran aktifitasnya. Oleh karena itu dibuatlah suatu peta hubungan aktifitas, di mana akan dapat diketahui bagaimana hubungan yang terjadi dan harus dipenuhi sesuai dengan tugas-tugas dan hubungan yang mendukung [8].

\section{Hollier Method}

Metode Hollier menggunakan data From to Chart perpindahan bahan antar fasilitas. Metode ini tidak membutuhkan data dimensi fasilitas serta tidak memerlukan penetapan awal fasilitas atau mesin yang akan ditata letak. Ada 2 metode Hollier, yaitu Hollier 1 dan Hollier 2. Perbedaan keduanya hanyalah untuk mempermudah proses pengaturan urutan mesin atau efisiensi dalam proses perhitungan [9].

\section{Activity Relation Diagram}

Activity Relation Diagram (ARD) adalah diagram hubungan antar aktivitas (departemen/mesin) berdasarkan tingkat prioritas kedekatan, sehingga diharapkan ongkos handling minimum. Dasar untuk membuat ARD adalah Tabel Skala Prioritas (TSP), jadi yang menempati prioritas pertama pada TSP harus didekatkan letaknya lalu diikuti prioritas berikutnya [1].

\section{Jarak Rectilinear}

Matriks Rectilinear ini disebut juga Manhattan, rightangle atau matriks rectangular. Cara ini umumnya banyak digunakan karena mudah untuk dihitung, mudah untuk dimengerti, dan sesuai untuk diterapkan dalam banyak masalah nyata [5].

\section{METODE PENELITIAN}

Penelitian ini diawali dengan penelusuran penelitian terdahulu yang dilakukan oleh [6], kemudian dilanjutkan dengan penentuan produk sebagai objek penelitian, jumlah mesin teoritis, jumlah mesin keseluruhan, luas lantai produksi, luas gudang bahan baku, dan luas gudang bahan jadi.

Penelitian dilanjutkan dengan menghitung Material Handling Planning Sheet (MHPS) dengan pendekatan Trapezoidal fuzzy number, From to 
Chart, Skala Prioritas, dan Tata Letak Usulan dengan metode DRM, Hollier 1 dan Hollier 2.

Perhitungan MHPS menggunakan pendekatan sistem fuzzy karena hasil yang diperoleh memiliki tingkat kesalahan yang lebih kecil dibandingkan metode MHPS konvensional.

Penelitian ini menganalisis kondisi tata letak lantai produksi saat ini, dan menghasilkan rancangan tata letak fasilitas lantai produksi berdasarkan jarak perpindahan material yang minimum.

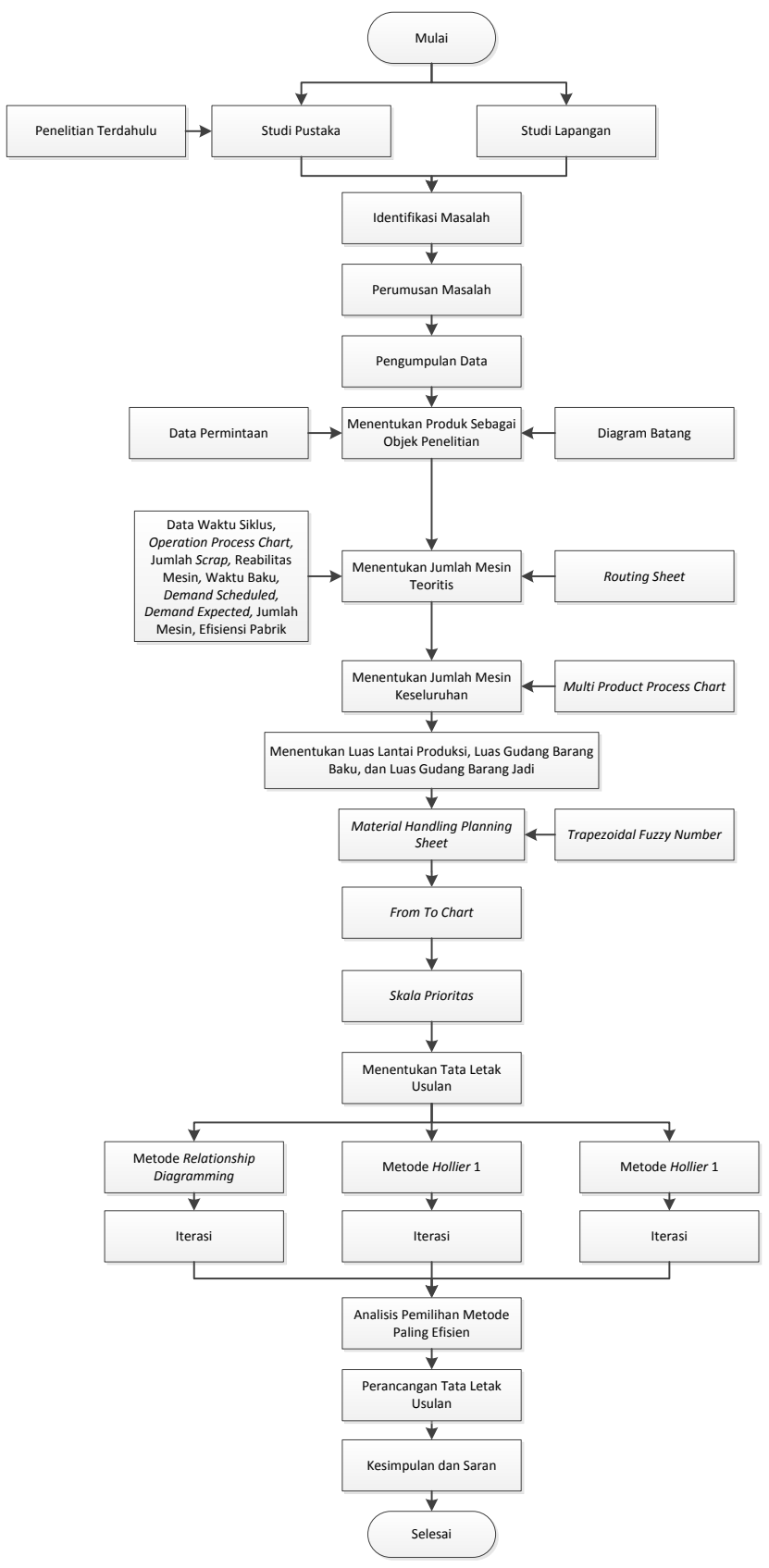

Gambar 1. Flowchart Metode Penelitian

\section{HASIL DAN PEMBAHASAN}

\section{Pemilihan Objek Penelitian}

Produk yang diteliti adalah jenis lemari dengan data penjualan paling banyak dari bulan Januari tahun 2010 hingga bulan Maret tahun 2012 yaitu lemari jenis LP 292 ATHENA. Alasan lain mengapa penulis menggunakan produk LP 292 ATHENA, dikarenakan setiap produk yang diproduksi oleh CV.XYZ memiliki waktu baku produksi yang relatif sama, hanya berbeda sedikit diproses pembuatan profil dengan menggunakan mesin ruter. Penentuan produk acuan diperoleh dari diagram batang semua jenis lemari yang diproduksi oleh CV. XYZ seperti ditunjukkan pada Gambar 2 berikut:

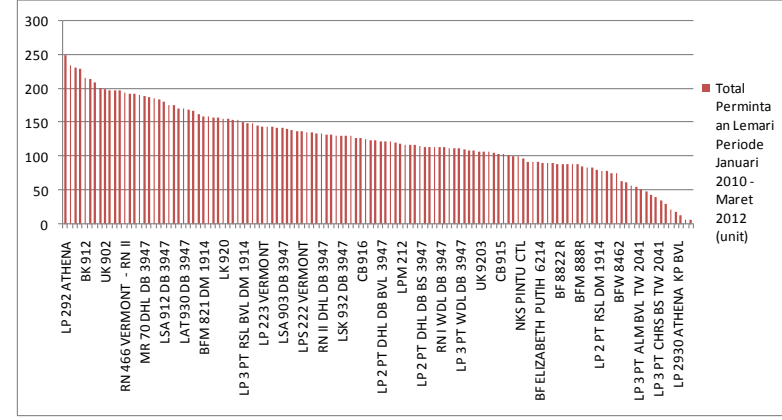

Gambar 2. Diagram Batang Data Penjualan Lemari

\section{Layout Awal}

Layout Awal pada penelitian ini seperti ditunjukan pada Gambar 3 berikut:

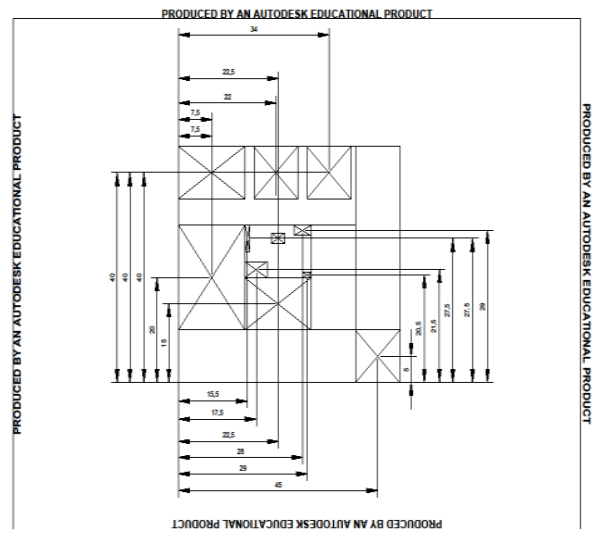

Gambar 3. Layout Awal

Total jarak yang dihitung untuk layout awal adalah sebesar 995 meter. 


\section{Peta Proses Operasi / Operation Process Chart (OPC)}

Gambar 4 menunjukkan Peta Proses Operasi yang memperlihatkan urutan operasi yang dilalui oleh suatu part atau produk.

\section{Routing Sheet}

Routing sheet digunakan untuk mengetahui jumlah permintaan yang dibutuhkan (scheduled demand) dan untuk mencari jumlah kebutuhan mesin. Oleh karena itu routing sheet ini terdiri dari persentase efisiensi pabrik, reliabilitas mesin, waktu baku (menit), jumlah scrap, expected demand (didapatkan dari hasil permintaan lemari jenis LP 292 ATHENA pada Maret 2012), scheduled demand, dan jumlah mesin. Tabel 1 dan Tabel 2 merupakan contoh Routing Sheet pada pembuatan pintu lemari:
Tabel 1. Routing Sheet Pintu Lemari

\begin{tabular}{ll}
\hline Part Name & $:$ Pintu Lemari \\
Pcs & $: 2$ \\
Efisiensi pabrik & $: 85 \%$ \\
\hline
\end{tabular}

Tabel 2. Routing Sheet Pintu Lemari (Lanjutan)

\begin{tabular}{lcccccc}
\hline $\begin{array}{c}\text { Deskripsi } \\
\text { Operasi }\end{array}$ & $\begin{array}{c}\text { Reabilitas } \\
\text { Mesin }\end{array}$ & Scrap & $\begin{array}{c}\text { Waktu Baku } \\
\text { (menit) }\end{array}$ & $\begin{array}{c}\text { Demand } \\
\text { Scheduled (unit) }\end{array}$ & $\begin{array}{c}\text { Demand } \\
\text { Expected (unit) }\end{array}$ & $\begin{array}{c}\text { Jumlah Mesin } \\
\text { Teoritis (unit) }\end{array}$ \\
\hline Pemotongan & $85 \%$ & $5 \%$ & 0.82 & 93.08 & 88.43 & 0.22 \\
Ruter & $75 \%$ & $15 \%$ & 3.45 & 88.43 & 75.16 & 1.00 \\
Vinyl & $80 \%$ & $5 \%$ & 2.35 & 75.16 & 71.41 & 0.54 \\
Pengeboran & $85 \%$ & $10 \%$ & 0.93 & 71.41 & 64.27 & 0.19 \\
Pengamplasan & $100 \%$ & $5 \%$ & 28.42 & 64.27 & 61.05 & 4.48 \\
Pendempulan & $100 \%$ & $0 \%$ & 9.70 & 61.05 & 61.05 & 1.45 \\
Pengamplasan & $100 \%$ & $5 \%$ & 16.72 & 61.05 & 58 & 2.50 \\
Pengecatan & $100 \%$ & $0 \%$ & 2.98 & 58 & 58 & 0.42 \\
Pernish & $100 \%$ & $0 \%$ & 1.20 & 58 & 58 & 0.17 \\
Pemeriksaan & - & $0 \%$ & - & 58 & 58 & - \\
\hline
\end{tabular}

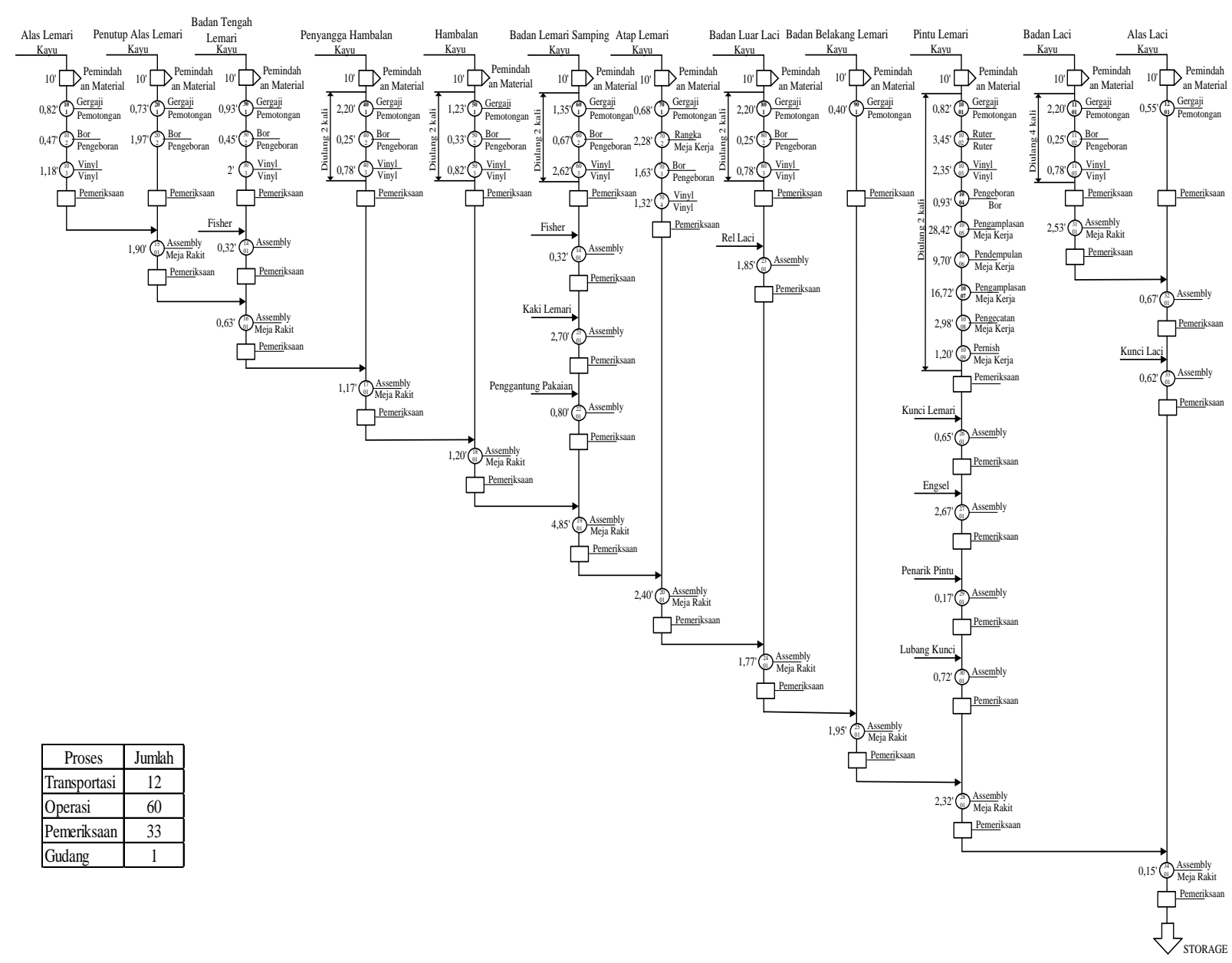

Gambar 4. Peta Proses Operasi 


\section{Multi Product Process Chart (MPPC)}

MPPC digunakan untuk menyusun dan mengetahui jumlah mesin yang dibutuhkan untuk setiap departemen (area mesin). MPPC pada penelitian ini seperti ditunjukan pada Tabel 3 berikut:

Tabel 3. Jumlah Mesin Sebenarnya Berdasarkan MPPC

\begin{tabular}{llcc}
\hline \multicolumn{1}{c}{ Work Station } & \multicolumn{1}{c}{ Deskripsi Operasi } & $\begin{array}{c}\text { Jumlah Mesin } \\
\text { Teoritis (unit) }\end{array}$ & $\begin{array}{c}\text { Jumlah Mesin } \\
\text { Sebenarnya (unit) }\end{array}$ \\
\hline Mesin Gergaji & Pemotongan & 2.97 & 3 \\
Mesin Bor & Pengeboran & 1.02 & 2 \\
Mesin Vinyl & Pemberian Vinyl Pada Sisi Lemari & 2.19 & 3 \\
Mesin Ruter & Pembuatan Profil & 1.00 & 1 \\
Meja Kerja Rangka & Pembuatan Rangka & 0.19 & 1 \\
Meja Kerja Pengamplasan & Pengamplasan & 6.98 & 7 \\
Meja Kerja Pendempulan & Pendempulan & 1.45 & 2 \\
Meja Keraja Pengecatan & Pengecatan & 0.59 & 1 \\
Meja Rakit & Assembly & 2.28 & 3 \\
\hline
\end{tabular}

\section{Luas Lantai Produksi}

Dengan Menggunakan allowance 40\% luas lantai produksi yang didapatkan seperti ditunjukkan pada Tabel 4 berikut:

Tabel 4. Luas Lantai Produksi

\begin{tabular}{lcccc}
\hline \multicolumn{1}{c}{ Work Station } & $\begin{array}{c}\text { Luas Workstation } \\
\left(\mathrm{m}^{2}\right)\end{array}$ & $\begin{array}{c}\text { Jumlah Mesin } \\
(\text { unit })\end{array}$ & $\begin{array}{c}\text { Luas Department } \\
\left(\mathrm{m}^{2}\right)\end{array}$ & $\begin{array}{c}\text { Luas dengan } \\
\text { Allowance }(\mathrm{m} 2)\end{array}$ \\
\hline Mesin Gergaji & 19.32 & 3 & 57.96 & 81.14 \\
Mesin Bor & 7.21 & 2 & 14.42 & 20.19 \\
Mesin Vinyl & 6.72 & 3 & 20.15 & 28.21 \\
Mesin Ruter & 5.29 & 1 & 5.29 & 7.40 \\
Meja Kerja Rangka & 2.03 & 1 & 2.03 & 2.84 \\
Meja Kerja Pengamplasan & 2.03 & 7 & 14.22 & 19.91 \\
Meja Kerja Pendempulan & 2.03 & 2 & 4.06 & 5.69 \\
Meja Kerja Pengecatan & 2.03 & 1 & 2.03 & 2.84 \\
Meja Rakit & 2.74 & 3 & 8.23 & 11.53 \\
\hline
\end{tabular}

Dari tabel di atas didapatkan luas lantai produksi sebesar $1796,79 \mathrm{~m}^{2}$.

\section{Material Handling Planning Sheet (MHPS)}

Material Handling Planning Sheet digunakan untuk mengetahui total bobot material handling dengan mengkalikan jarak dengan biaya. Pada penelitian ini untuk mengetahui bobot material handling digunakan pendekatan TrFN. Berikut merupakan langkah-langkah dalam melakukan perhitungan TrFN.

\section{Penentuan Linguistik}

Tahap pertama yang dilakukan adalah fuzzifikasi, dalam hal ini adalah penentuan linguistik untuk penentuan kriteria kesesuaian jarak dan biaya.

Tabel 5. Tahap Fuzzyfikasi Linguistik Jarak

\begin{tabular}{lccc}
\hline \multicolumn{1}{c}{ Linguistik } & & Skala & Selang (m) \\
\hline Sangat Dekat & SD & 1 & $1-10$ \\
Dekat & D & 2 & $8-20$ \\
Cukup Dekat & CD & 3 & $18-30$ \\
Tidak Perlu Dekat & TD & 4 & $28-40$ \\
Sangat Tidak Perlu Dekat & STD & 5 & $38-50$ \\
\hline
\end{tabular}

Tabel 6. Tahap Fuzzyfikasi Linguistik Biaya

\begin{tabular}{lccc}
\hline \multicolumn{1}{c}{ Linguistik } & & Skala & Selang (m) \\
\hline Sangat Dekat & SD & 1 & $500-900$ \\
Dekat & D & 2 & $750-1300$ \\
Cukup Dekat & CD & 3 & $1150-1700$ \\
Tidak Perlu Dekat & TD & 4 & $1550-2100$ \\
Sangat Tidak Perlu Dekat & STD & 5 & $1950-2500$ \\
\hline
\end{tabular}

Tabel 7. Hasil TrFN Jarak

\begin{tabular}{lcc}
\hline \multicolumn{1}{c}{ Linguistik } & & TrFN Jarak \\
\hline Sangat Dekat & SD & $(1 ; 1 ; 5,5 ; 10)$ \\
Dekat & D & $(8 ; 12 ; 16 ; 20)$ \\
Cukup Dekat & CD & $(18 ; 22 ; 26 ; 30)$ \\
Tidak Perlu Dekat & TD & $(28 ; 32 ; 36 ; 40)$ \\
Sangat Tidak Perlu Dekat & STD & $(38 ; 42 ; 46 ; 50)$ \\
\hline
\end{tabular}

Tabel 8. Hasil TrFN Biaya

\begin{tabular}{lcc}
\hline \multicolumn{1}{c}{ Linguistik } & & TrFN Biaya \\
\hline Sangat Dekat & SD & $(500 ; 500 ; 700 ; 900)$ \\
Dekat & D & $(750 ; 933,33 ; 1116,67 ; 1300)$ \\
Cukup Dekat & CD & $(1150 ; 1333,33 ; 1516,67 ; 2100)$ \\
Tidak Perlu Dekat & TD & $(1550 ; 1733,33 ; 1916,67 ; 2100)$ \\
Sangat Tidak Perlu Dekat & STD & $(1950 ; 2133,33 ; 2316,67 ; 2500)$ \\
\hline
\end{tabular}

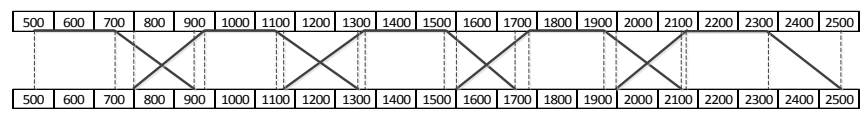

Gambar 5. Derajat Keanggotaan TrFNJarak

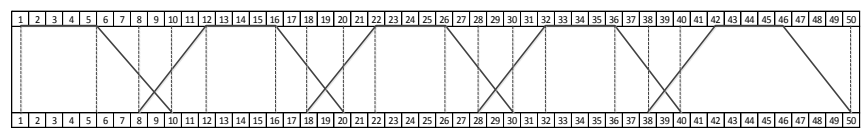

Gambar 6. Derajat Keanggotaan TrFNBiaya

\section{Pendapat Pakar}

Peneliti menggunakan dua pakar dalam penelitian ini, yaitu ibu Ribka dan Ibu Natalia.

\section{Penghitungan Rata-Rata Geometri}

Untuk menggabungkan pendapat pakar dilakukan perhitungan rata-rata geometri. Hal ini dilakukan karena ada 2 pakar yang dimintai pendapat dalam menghasilkan perhitungan MHPS. 
Tabel 9. Pendapat Pakar

\begin{tabular}{|c|c|c|c|c|c|c|c|c|c|c|c|c|c|c|c|c|c|c|c|c|c|}
\hline \multirow{2}{*}{$\begin{array}{c}\text { Fasilitas } \\
\text { Pendapat Pakar }\end{array}$} & $\begin{array}{c}1 \\
\text { Guddang Bahan Baku } \\
\end{array}$ & \multicolumn{2}{|c|}{$\begin{array}{c}2 \\
\text { Mesin Gergaji } \\
\end{array}$} & \multicolumn{2}{|c|}{$\begin{array}{c}3 \\
\text { Mesin Bor } \\
\end{array}$} & \multicolumn{2}{|c|}{$\begin{array}{c}4 \\
\text { Mesin Vingl } \\
\end{array}$} & \multicolumn{2}{|c|}{$\begin{array}{c}5 \\
\text { Mesin Ruter } \\
\end{array}$} & \multicolumn{2}{|c|}{$\begin{array}{c}6 \\
\text { Meja Kerja Rangka } \\
\end{array}$} & \multicolumn{2}{|c|}{$\begin{array}{c}7 \\
\text { Meja Kerja } \\
\end{array}$} & \multicolumn{2}{|c|}{$\begin{array}{c}8 \\
\text { Meja Kerja } \\
\end{array}$} & \multicolumn{2}{|c|}{$\begin{array}{c}9 \\
\text { Meja Kerja } \\
\end{array}$} & \multicolumn{2}{|c|}{$\begin{array}{c}10 \\
\text { Meja Rakit } \\
\end{array}$} & \multicolumn{2}{|c|}{$\begin{array}{c}11 \\
\text { Gudang Barang Jadi }\end{array}$} \\
\hline & 12 & 1 & 2 & 1 & 2 & 1 & 2 & 1 & 2 & 1 & 2 & 1 & 2 & 1 & 2 & 1 & 2 & 1 & 2 & 1 & 2 \\
\hline 1 Gudang Bahan Baku & & SD & SD & $C D$ & D & $C D$ & $D$ & $C D$ & $\mathrm{D}$ & D & D & STD & $C D$ & STD & $C D$ & STD & $C D$ & STD & $\mathrm{TD}$ & STD & STD \\
\hline 2 Mesin Gergäil & & & & SD & SD & $\mathrm{D}$ & $\mathrm{D}$ & SD & SD & D & D & STD & $C D$ & STD & $C D$ & STD & $C D$ & STD & $\mathrm{TD}$ & STD & STD \\
\hline 3 Mesin Bor & & & & & & $\mathrm{D}$ & SD & D & $\mathrm{D}$ & $D$ & D & STD & $C D$ & STD & $C D$ & STD & $C D$ & STD & $\mathrm{TD}$ & STD & STD \\
\hline 4 Mesin Vinyl & & & & & & & & D & D & $C D$ & D & STD & $C D$ & STD & $C D$ & STD & $C D$ & STD & $C D$ & STD & STD \\
\hline 5 Mesin Ruter & & & & & & & & & & $C D$ & D & STD & $C D$ & STD & $C D$ & STD & $C D$ & STD & $\mathrm{TD}$ & STD & STD \\
\hline 6 Meja Kerja Rangka & & & & & & & & & & & & STD & $\mathrm{TD}$ & STD & $\mathbb{D D}$ & STD & $\mathrm{TD}$ & STD & $C D$ & STD & STD \\
\hline 7 Meja Kerja Pengamplasan & & & & & & & & & & & & & & SD & SD & D & SD & $C D$ & $\mathrm{D}$ & $C D$ & $C D$ \\
\hline 8 Meja Kerja Pendenpulan & & & & & & & & & & & & & & & & D & D & $C D$ & $\mathrm{D}$ & $C D$ & $C D$ \\
\hline 9 Meja Kerja Pengecatan & & & & & & & & & & & & & & & & & & D & SD & D & $D$ \\
\hline 10 Meja Rakit & & & & & & & & & & & & & & & & & & & & SD & SD \\
\hline 11 Gudang Barang Jadi & & & & & & & & & & & & & & & & & & & & & \\
\hline
\end{tabular}

\section{Biaya Material Handling}

Tabel 10. Penentuan Biaya Material Handling Berdasarkan Pendapat Pakar

\begin{tabular}{llcr}
\multicolumn{1}{c}{ Dari } & \multicolumn{1}{c}{ Fesilitas } & Linguistik & $\begin{array}{c}\text { Biaya Material } \\
\text { Handling (Rp.m) }\end{array}$ \\
\hline Gudang Bahan Baku & Mesin Gergaji & SD & $13,850.00$ \\
Gudang Bahan Baku & Mesin Bor & D & $61,066.67$ \\
Gudang Bahan Baku & Mesin Vinyl & CD & $140,466.67$ \\
Gudang Bahan Baku & Mesin Ruter & CD & $140,466.67$ \\
Gudang Bahan Baku & Meja Kerja Rangka & D & $61,066.67$ \\
Gudang Bahan Baku & Meja Kerja Pengamplasan & TD & $251,866.67$ \\
Gudang Bahan Baku & Meja Kerja Pendempulan & TD & $251,866.67$ \\
Gudang Bahan Baku & Meja Kerja Pengecatan & TD & $251,866.67$ \\
Gudang Bahan Baku & Meja Rakit & STD & $395,266.67$ \\
Gudang Bahan Baku & Gudang Barang Jadi & STD & $395,266.67$ \\
Mesin Gergaji & Mesin Bor & SD & $13,850.00$ \\
Mesin Gergaji & Mesin Vinyl & D & $61,066.67$ \\
Mesin Gergaji & Mesin Ruter & SD & $13,850.00$ \\
Mesin Gergaji & Meja Kerja Rangka & D & $61,066.67$ \\
Mesin Gergaji & Meja Kerja Pengamplasan & TD & $251,866.67$ \\
Mesin Gergaji & Meja Kerja Pendempulan & TD & $251,866.67$ \\
Mesin Gergaji & Meja Kerja Pengecatan & TD & $251,866.67$ \\
Mesin Gergaji & Meja Rakit & STD & $395,266.67$ \\
Mesin Gergaji & Gudang Barang Jadi & STD & $395,266.67$ \\
Mesin Bor & Mesin Vinyl & SD & $13,850.00$ \\
Mesin Bor & Mesin Ruter & D & $61,066.67$ \\
Mesin Bor & Meja Kerja Rangka & D & $61,066.67$ \\
Mesin Bor & Meja Kerja Pengamplasan & TD & $251,866.67$ \\
Mesin Bor & Meja Kerja Pendempulan & TD & $251,866.67$ \\
Mesin Bor & STdang Barang Jadi & $251,866.67$ \\
Mesin Bor & TD & $395,266.67$ \\
\hline Mesin Bor & STengecatan & $395,266.67$ \\
\hline
\end{tabular}

Tabel 11. Penentuan Biaya Material Handling Berdasarkan Pendapat Pakar (Lanjutan)

\begin{tabular}{|c|c|c|c|}
\hline \multicolumn{2}{|c|}{ Fasilitas } & \multirow{2}{*}{ Linguistik } & \multirow{2}{*}{$\begin{array}{r}\text { Biaya Material } \\
\text { Handling (Rp.m) }\end{array}$} \\
\hline Dari & $\mathrm{Ke}$ & & \\
\hline Mesin Vinyl & Mesin Ruter & $\mathrm{D}$ & $61,066.67$ \\
\hline Mesin Vinyl & Meja Kerja Rangka & $\mathrm{CD}$ & $140,466.67$ \\
\hline Mesin Vinyl & Meja Kerja Pengamplasan & TD & $251,866.67$ \\
\hline Mesin Vinyl & Meja Kerja Pendempulan & $\mathrm{TD}$ & $251,866.67$ \\
\hline Mesin Vinyl & Meja Kerja Pengecatan & TD & $251,866.67$ \\
\hline Mesin Vinyl & Meja Rakit & TD & $251,866.67$ \\
\hline Mesin Vinyl & Gudang Barang Jadi & STD & $395,266.67$ \\
\hline Mesin Ruter & Meja Kerja Rangka & $\mathrm{D}$ & $61,066.67$ \\
\hline Mesin Ruter & Meja Kerja Pengamplasan & TD & $251,866.67$ \\
\hline Mesin Ruter & Meja Kerja Pendempulan & $\mathrm{TD}$ & $251,866.67$ \\
\hline Mesin Ruter & Meja Kerja Pengecatan & TD & $251,866.67$ \\
\hline Mesin Ruter & Meja Rakit & STD & $395,266.67$ \\
\hline Mesin Ruter & Gudang Barang Jadi & STD & $395,266.67$ \\
\hline Meja Kerja Rangka & Meja Kerja Pengamplasan & STD & $395,266.67$ \\
\hline Meja Kerja Rangka & Meja Kerja Pendempulan & STD & $395,266.67$ \\
\hline Meja Kerja Rangka & Meja Kerja Pengecatan & STD & $395,266.67$ \\
\hline Meja Kerja Rangka & Meja Rakit & $\mathrm{TD}$ & $251,866.67$ \\
\hline Meja Kerja Rangka & Gudang Barang Jadi & STD & $395,266.67$ \\
\hline Meja Kerja Pengamplasan & Meja Kerja Pendempulan & SD & $13,850.00$ \\
\hline Meja Kerja Pengamplasan & Meja Kerja Pengecatan & SD & $13,850.00$ \\
\hline Meja Kerja Pengamplasan & Meja Rakit & $\mathrm{CD}$ & $140,466.67$ \\
\hline Meja Kerja Pengamplasan & Gudang Barang Jadi & $\mathrm{CD}$ & $140,466.67$ \\
\hline Meja Kerja Pendempulan & Meja Kerja Pengecatan & D & $61,066.67$ \\
\hline Meja Kerja Pendempulan & Meja Rakit & $\mathrm{CD}$ & $140,466.67$ \\
\hline Meja Kerja Pendempulan & Gudang Barang Jadi & $\mathrm{CD}$ & $140,466.67$ \\
\hline Meja Kerja Pengecatan & Meja Rakit & SD & $13,850.00$ \\
\hline Meja Kerja Pengecatan & Gudang Barang Jadi & $\mathrm{D}$ & $61,066.67$ \\
\hline Meja Rakit & Gudang Barang Jadi & SD & 13,850 \\
\hline
\end{tabular}

\section{From To Chart (FTC)}

FTC diisi oleh material handling yang didapat dari hasil perhitungan MHPS dengan menggunakan pendekatan Trapezoidal Fuzzy. 
Tabel 12. FTC Biaya Material Handling

\begin{tabular}{|c|c|c|c|c|c|c|c|c|c|c|c|}
\hline Fasilitas & 1 & 2 & 3 & 4 & 5 & 6 & 7 & 8 & 9 & 10 & 11 \\
\hline Dari|Ke & $\begin{array}{c}\text { Gudang } \\
\text { Bahan Baku }\end{array}$ & $\begin{array}{c}\text { Mesin } \\
\text { Gergaji }\end{array}$ & $\begin{array}{l}\text { Mesin } \\
\text { Bor }\end{array}$ & Mesin Vinyl & $\begin{array}{l}\text { Mesin } \\
\text { Ruter }\end{array}$ & $\begin{array}{c}\text { Meja Kerja } \\
\text { Rangka }\end{array}$ & $\begin{array}{c}\text { Meja Kerja } \\
\text { Pengamplasan }\end{array}$ & $\begin{array}{c}\text { Meja Kerja } \\
\text { Pendempulan }\end{array}$ & $\begin{array}{l}\text { Meja Kerja } \\
\text { Pengecatan }\end{array}$ & Meja Rakit & $\begin{array}{c}\text { Gudang } \\
\text { Barang Jadi }\end{array}$ \\
\hline 1 Gudang Bahan Baku & & 13,850 & 61,067 & 140,467 & 140,467 & 61,067 & 251,867 & 251,867 & 251,867 & 395,267 & 395,267 \\
\hline 2 Mesin Gergaji & & & 13,850 & 61,067 & 13,850 & 61,067 & 251,867 & 251,867 & 251,867 & 395,267 & 395,267 \\
\hline 3 Mesin Bor & & & & & 61,067 & & 251,867 & 251,867 & 251,867 & 395,267 & 395,267 \\
\hline 4 Mesin Vinyl & & & 13,850 & & & 140,467 & 251,867 & 251,867 & 251,867 & 251,867 & 395,267 \\
\hline 5 Mesin Ruter & & & & 61,067 & & 61,067 & 251,867 & 251,867 & 251,867 & 395,267 & 395,267 \\
\hline 6 Meja Kerja Rangka & & & 61,067 & & & & 395,267 & 395,267 & 395,267 & 251,867 & 395,267 \\
\hline 7 Meja Kerja Pengamplasan & & & & & & & & 13,850 & 13,850 & 140,467 & 140,467 \\
\hline 8 Meja Kerja Pendempulan & & & & & & & 13,850 & & 61,067 & 140,467 & 140,467 \\
\hline 9 Meja Kerja Pengecatan & & & & & & & & & & 13,850 & 61,067 \\
\hline 10 Meja Rakit & & & & & & & & & & & 13,850 \\
\hline \multicolumn{12}{|l|}{11 Gudang Barang Jadi } \\
\hline Total & 0 & 13,850 & 149,833 & 262,600 & 215,383 & 323,667 & $1,668,450$ & $1,668,450$ & $1,729,517$ & $2,379,583$ & $2,727,450$ \\
\hline
\end{tabular}

Tabel 13. Koefisien Inflow FTC

\begin{tabular}{|c|c|c|c|c|c|c|c|c|c|c|c|}
\hline Fasilitas & 1 & 2 & 3 & 4 & 5 & 6 & 7 & 8 & 9 & 10 & 11 \\
\hline Dari|Ke & $\begin{array}{c}\text { Gudang } \\
\text { Bahan Baku }\end{array}$ & $\begin{array}{c}\text { Mesin } \\
\text { Gergaji }\end{array}$ & $\begin{array}{c}\text { Mesin } \\
\text { Bor }\end{array}$ & $\begin{array}{r}\text { Mesin } \\
\text { Vinyl } \\
\end{array}$ & Mesin Ruter & $\begin{array}{c}\text { Meja Kerja } \\
\text { Rangka }\end{array}$ & $\begin{array}{c}\text { Meja Kerja } \\
\text { Pengamplasan }\end{array}$ & $\begin{array}{c}\text { Meja Kerja } \\
\text { Pendempulan }\end{array}$ & $\begin{array}{l}\text { Meja Kerja } \\
\text { Pengecatan }\end{array}$ & $\begin{array}{l}\text { Meja } \\
\text { Rakit }\end{array}$ & $\begin{array}{c}\text { Gudang } \\
\text { Barang Jadi }\end{array}$ \\
\hline 1 Gudang Bahan Baku & & 1 & 0.41 & 0.53 & 0.65 & 0.19 & 0.15 & 0.15 & 0.15 & 0.17 & 0.14 \\
\hline 2 Mesin Gergaji & & & 0.09 & 0.23 & 0.06 & 0.19 & 0.15 & 0.15 & 0.15 & 0.17 & 0.14 \\
\hline 3 Mesin Bor & & & & & 0.28 & & 0.15 & 0.15 & 0.15 & 0.17 & 0.14 \\
\hline 4 Mesin Vinyl & & & 0.09 & & & 0.43 & 0.15 & 0.15 & 0.15 & 0.11 & 0.14 \\
\hline 5 Mesin Ruter & & & & 0.23 & & 0.19 & 0.15 & 0.15 & 0.15 & 0.17 & 0.14 \\
\hline 6 Meja Kerja Rangka & & & 0.41 & & & & 0.24 & 0.24 & 0.23 & 0.11 & 0.14 \\
\hline 7 Meja Kerja Pengamplasan & & & & & & & & 0.01 & 0.01 & 0.06 & 0.05 \\
\hline 8 Meja Kerja Pendempulan & & & & & & & 0.01 & & 0.04 & 0.06 & 0.05 \\
\hline 9 Meja Kerja Pengecatan & & & & & & & & & & 0.01 & 0.02 \\
\hline 10 Meja Rakit & & & & & & & & & & & 0.01 \\
\hline 11 Gudang Barang Jadi & & & & & & & & & & & \\
\hline
\end{tabular}

\section{Relationship Diagramming Method}

Pada metode ini, kegiatan yang pertama kali dilakukan adalah membuat tabel skala prioritas yang diisi secara subjektif oleh peneliti mengacu pada ketentuan skala kedekatan seperti yang ditunjukkan pada Tabel 14.

Selanjutnya setelah menentukan skala kedekatan, kemudian dibuat tabel skala prioritas seperti disajikan pada Tabel 15.

Tabel 14. Skala Kedekatan Relationship Diagramming Method

\begin{tabular}{ll}
\hline Kode & Keterangan \\
\hline A & Harus Sangat Dekat \\
E & Sangat Dekat \\
I & Dekat \\
O & Cukup Dekat \\
U & Tidak Perlu Dekat \\
X & Sangat Tidak Perlu Dekat \\
\hline
\end{tabular}

Tabel 15. Skala Prioritas

\begin{tabular}{lcccccc}
\hline \multirow{2}{*}{ No Nama Mesin } & \multicolumn{7}{c}{ Skala Kedekatan } \\
\cline { 2 - 7 } & A & E & I & O & U & X \\
\hline 1 Gudang Bahan Baku & 2 & 5 & 4 & 3 & $6,7,8,9,10,11$ & \\
2 Mesin Gergaji & 4 & 6 & 10 & $7,8,9$ & 3.11 & \\
3 Mesin Bor & 5 & 10 & $7,8,9$ & 11 & & \\
4 Mesin Vinyl & 6 & $7,8,9$ & 11 & 10 & 3 & \\
5 Mesin Ruter & 4 & 6 & 10 & $7,8,9$ & 11 & \\
6 Meja Kerja Rangka & 3 & 7.8 & 9 & 11 & 10 & \\
7 Meja Kerja Pengamplasan & 10 & 11 & 8,9 & & & \\
8 Meja Kerja Pendempulan & 10 & 11 & 9 & 7 & & \\
9 Meja Kerja Pengecatan & 11 & 10 & & & & \\
10 Meja Rakit & 11 & & & & & \\
11 Gudang Barang Jadi & & & & &
\end{tabular}

Setelah itu dibuat Area Relationship Diagram (ARD) seperti disajikan pada Gambar 7.

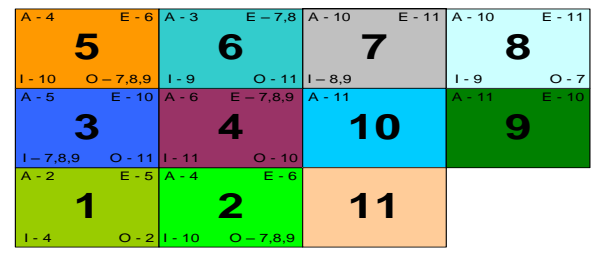

Gambar 7 ARD Relationship Diagramming Method

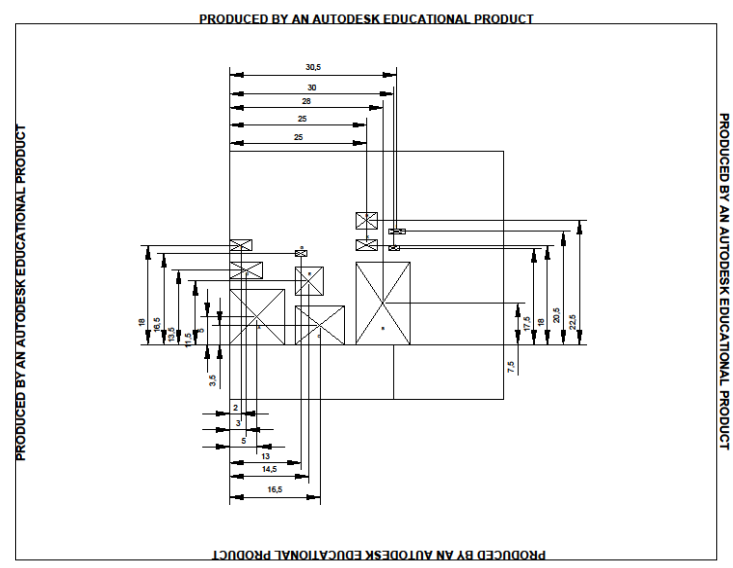

Gambar 8 Layout Relationship Diagramming Method 
Total jarak yang untuk layout Relationship Diagramming Method diperoleh sebesar 826,5 meter seperti disajikan pada Gambar 8 .

\section{Hollier 1 Method}

Pada metode ini, yang harus dilakukan pertama kali adalah menjumlahkan tiap baris dan kolom pada FTC Inflow. Kemudian dilakukan iterasi. Pada penelitian ini terdapat 10 iterasi. Setelah dilakukan iterasi didapatkan susunan tata letak yaitu 1-2-3-54-6-7-8-9-10-11. Setelah itu dibuat Area Relationship Diagram (ARD) yang disajikan pada Gambar 9.

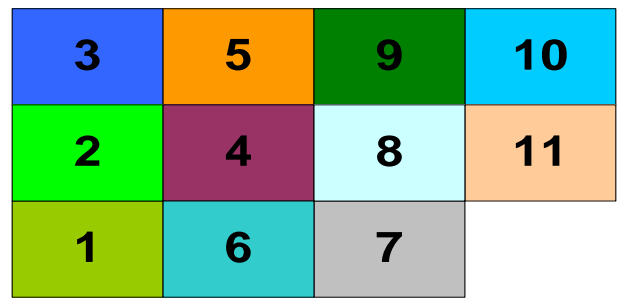

Gambar 9. ARD Hollier 1 Method

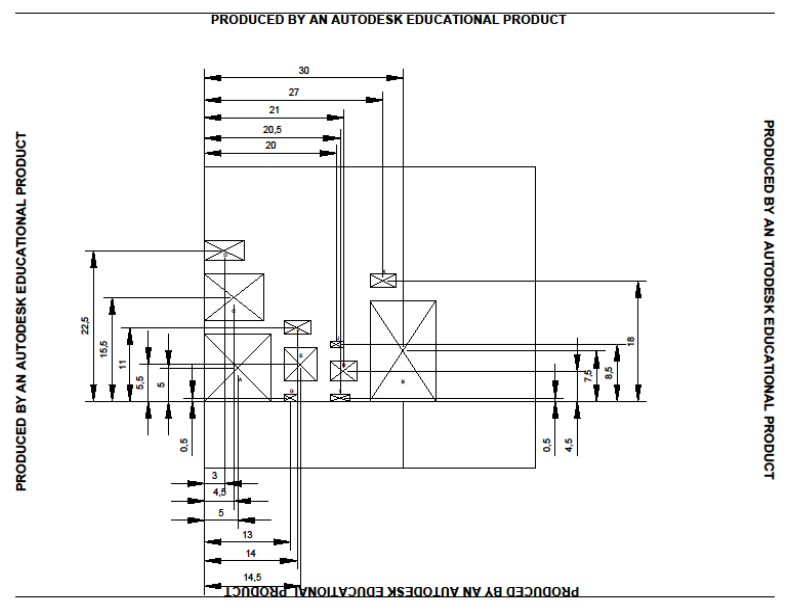

Gambar 10. Layout Hollier 1 Method

Total jarak yang untuk layout Hollier 1 Method diperoleh sebesar 890,5 meter seperti disajikan pada Gambar 10.

\section{Hollier 2 Method}

Pada metode ini, hanya perlu dicari rasio semua dari penjumlahan baris dan kolom kemudian urutkan dari yang bernilai rasio paling besar hingga paling kecil. Setelah didapatkan susunan tata letak sebagai berikut 1-2-3-5-4-6-8-7-9-10-11. Maka setelah itu dibuat Area Relationship Diagram (ARD) yang disajikan pada Gambar 11 .

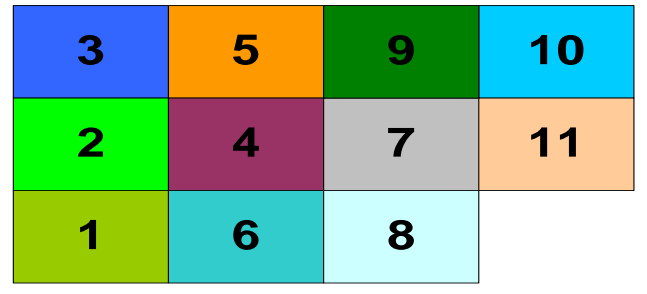

Gambar 11. ARD Hollier 2 Method

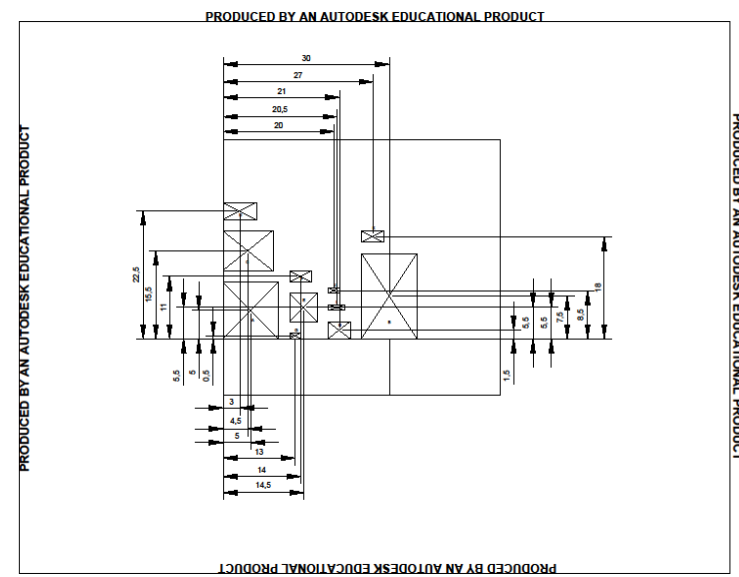

Gambar 12. Layout Hollier 2 Method

Total jarak yang untuk layout Hollier 1 Method diperoleh sebesar 896,5 meter seperti disajikan pada Gambar 12.

\section{Ekstraksi}

Dari ketiga metode yang digunakan, diperoleh total jarak rectilinier yang berbeda-beda. Pada ketiga metode didapatkan hasil yang lebih kecil dibandingkan layout awal, artinya ketiga metode tersebut menghasilkan layout yang lebih efisien. Dari ketiga metode tersebut, hasil total jarak yang paling kecil yaitu dengan menggunakan RDM.

\section{KESIMPULAN DAN SARAN}

\section{Kesimpulan}

Kesimpulan yang bisa ditarik dari penelitian ini untuk menjawab perumusan permasalaan yang ada adalah:

1. Dari hasil perhitungan dengan tiga metode didapat total jarak paling efisien adalah total jarak yang paling kecil diantara layout awal dan juga layout yang menggunakan metode RDM sebesar 826.5 meter. Metode ini menghasilkan tata letak fasilitas usulan yang memiliki jarak perpindahan material yang lebih kecil dari tata letak fasilitas lantai produksi yang digunakan perusahaan saat ini. 
2. Besar pengurangan yang terjadi pada total jarak perpindahan material antar mesin adalah 98,5 meter, didapatkan dari total jarak layout awal dikurangi total jarak layout RDM.

\section{Saran}

1. Diharapkan agar penelitian ini dapat dipertimbangkan perusahaan sebagai solusi alternatif dalam pemecahan masalah yang dihadapi pada bagian lantai produksi agar diperoleh layout yang lebih efisien dalam proses produksi.

2. Peletakan dari setiap departemen (area mesin) hendaknya memperhatikan keefektifan dalam pemindahan bahan sehingga tidak memakan waktu dan biaya dalam pemindahannya.

3. Dalam pemilihan rancangan yang lebih baik, penelitian ini hanya melihat dari satu kriteria kuantitatif yaitu jarak perpindahan material. Oleh karena itu diperlukan penelitian yang lebih lanjut dengan mempertimbangkan kriteria lainnya seperti aliran yang lancar, bentuk material, ukuran, bobot material, waktu pemindahan bahan, dan biaya produksi.

\section{DAFTAR PUSTAKA}

[1]. J. M. Apple, Tata Letak Pabrik dan Pemindahan Bahan. Penerjemah: Nurhayati Mardiono. Bandung: ITB. 1990.

[2]. S. Wignjosoebroto, Tata Letak Pabrik dan Pemindahan Bahan. Edisi Ketiga. Penerbit Guna Widya, Surabaya, 2003.

[3]. IZ. Sutalaksana, dkk. 2001. Teknik dan Tata Cara Kerja, ITB. Departemen Teknik Industri

[4]. JA. Tompkins, AW. John, AB. Yavuz, HF. Edward, J M A Tanchoco, J. Trevino. Facilities Planning Second Edition. John Willey \& Sons, INC., New York. 1996.

[5]. H. Purnomo. Perencanaan dan Perancangan Fasilitas, Penerbit Graha Ilmu, Yogyakarta, 2004.

[6]. N. Nurhasanah, Marimin. Fuzzy Technique Application in Production Planning at PT. XYZ. Proceeding International Seminar on Industrial Engineering and Management ISIEM. 2008.

[7]. Gen, M. \& Cheng, R. Genetic Algorithm and Engineering Design. New York : John Wiley \& Sons, Inc. 1997.

[8]. AA. Pradipta. Analisis Tata Letak Fasilitas pada Lantai Produksi PT. Louserindo Megah Permai. Jakarta: Teknik Industri Universitas Al-Azhar Indonesia. 2011.

[9]. R.A. Hadiguna, E. Wirdianto, Model Penyelesaian Masalah Pemilihan Alternatif Tata Letak, Jurnal Sains dan Teknologi STTIND. 2003. 